\title{
Prior hepatitis B virus infection as a co- factor of chronic hepatitis $C$ patient survival after resection of hepatocellular carcinoma
}

\author{
Yutaka Midorikawa ${ }^{1 *}$, Tadatoshi Takayama ${ }^{1 *}$, Hisashi Nakayama', Tokio Higaki ${ }^{1}$, Masamichi Moriguchi', \\ Kyoji Moriya ${ }^{2}$, Tatsuo Kanda ${ }^{3}$, Shunichi Matsuoka ${ }^{3}$ and Mitsuhiko Moriyama ${ }^{3}$
}

\begin{abstract}
Background: Prior hepatitis B virus infection (PBI) may increase the risk of developing hepatocellular carcinoma (HCC), but the impact of PBI on clinical outcomes following treatment for HCC remains unknown. The aim of this study was to clarify whether PBI affects clinical outcomes after liver resection for hepatitis C virus (HCV)-related HCC by retrospective cohort study.

Methods: PBI patients were defined as those negative for hepatitis B surface antigen and positive for anti-hepatitis B core antibody. Surgical outcomes of HCV-related HCC patients with PBI were compared to those without PBI. Survival of patients with non-B non-C HCC with and without PBI were also compared.

Results: In the HCV group, the median overall survival of 165 patients with PBI was 4.7 years (95\% confidence interval [CI], 3.9-5.9), and was significantly shorter compared with 263 patients without PBI (6.6 years [5.3-9.8]; $p=0.015)$. Conversely, there was no significant difference in recurrence-free survival between the two groups (1.8 years $[95 \% \mathrm{Cl}, 1.4-2.0]$ vs 2.0 years $[1.7-2.3] ; p=0.205)$. On Cox proportional hazards regression model, independent factors for overall survival were PBI (hazard ratio $1.38[95 \% \mathrm{Cl}, 1.02-1.87]$; $p=0.033$ ), multiple tumors $(p=0.007)$, tumor size $(p=0.002)$, and liver cirrhosis $(p<0.001)$. On the other hand, in the non-B nonC HCC group, both the median overall survival (6.5 years $[95 \% \mathrm{Cl}, 4.8-7.1])$ and recurrence-free survival (2.4 years, [95\% Cl, 1.5-3.3]) in 104 patients with PBI were not significantly different from those (7.5 years [5.5 - NA; $p=0.932]$; and 2.2 years $[1.7-2.7 ; p=0.983]$ ) in 213 patients without PBI.
\end{abstract}

Conclusions: $\mathrm{PBI}$ and HCV in conjunction with each other affect the survival of patients that have undergone resection for HCC.

Keywords: Prior hepatitis B virus infection, Chronic hepatitis C virus infection, Liver resection, Hepatocellular carcinoma

\section{Background}

Prior hepatitis $B$ virus (HBV) infection (PBI) is evidenced by isolated IgG anti hepatitis B core antibody (HBcAb) positivity, while occult HBV infection (OBI) is defined as the presence of HBV DNA in the liver of patients without hepatitis B surface antigen (HBsAg) [1]. Despite the disappearance of serum HBsAg after spontaneous regression or hepatitis $B$ treatment with nucleoside

\footnotetext{
*Correspondence: mido-tky@umin.ac.jp; takayama.tadatoshi@nihon-u.ac.jp ${ }^{1}$ Department of Digestive Surgery, Nihon University School of Medicine, 30-1, Oyaguchikami-cho, Itabashi-ku, Tokyo 173-8610, Japan

Full list of author information is available at the end of the article
}

analogues, for example, some patients are at risk of developing hepatocellular carcinoma (HCC) $[2,3]$.

$\mathrm{PBI}$ or OBI may play a pivotal role in the progression of liver fibrosis in patients with chronic hepatitis $\mathrm{C}$ virus (HCV) infection [4-7], and may also be a risk factor for HCC by indirectly causing persistent hepatic inflammation and fibrosis, as well as through its direct proto-oncogenic effect $[4,8,9]$. Consequently, OBI as a co-factor could impact the life-expectancy of chronic HCV patients with OBI compared with those without OBI [9]. However, there are several conflicting reports that indicate there is no association between PBI or OBI and the progression to

(c) The Author(s). 2019 Open Access This article is distributed under the terms of the Creative Commons Attribution 4.0 International License (http://creativecommons.org/licenses/by/4.0/), which permits unrestricted use, distribution, and reproduction in any medium, provided you give appropriate credit to the original author(s) and the source, provide a link to the Creative Commons license, and indicate if changes were made. The Creative Commons Public Domain Dedication waiver (http://creativecommons.org/publicdomain/zero/1.0/) applies to the data made available in this article, unless otherwise stated. 
cirrhosis in chronic HCV patients [10, 11]. Likewise, neither prior exposure to HBV nor OBI are significant factors in HCC development in chronic HCV patients [12-14]. However, there have been a few reports from a small cohort on an association between previous infection of HBV and clinical outcome following treatment for HCC $[15,16]$. Thus, the impact of PBI or OBI on clinical outcomes of chronic HCV patients remains controversial and unresolved [17].

Reactivation of HBV, both in prior and overt infection, is characterized by a marked enhancement of viral replication under immunosuppressive conditions [18-20]. Therefore, PBI itself does not seem to exacerbate chronic liver disease preceding hepatocarcinogenesis, but may negatively influence the outcomes of chronic liver disease through the co-existence of other related diseases such as HCV or human immunodeficiency virus infection [21].

The aim of the current study was to demonstrate whether PBI and HCV could co-affect the clinical outcomes of patients undergoing liver resection for HCC.

\section{Methods}

\section{Patients}

From 2004 to 2016, HBsAg-negative patients who underwent curative liver resection for $\mathrm{HCC}$ in Nihon University Itabashi Hospital were included in this study. Each participant provided written, informed consent, and this study was approved by the institutional review board of Nihon University. All patients were closely observed during each outpatient visit post-surgery. PBI patients were defined as those who were negative for HBsAg, but positive for $\mathrm{HBcAb}[22,23]$. HCV patients were defined as those positive for $\mathrm{HCV}$ antibody and HCV-RNA detected. Clinical characteristics and outcomes were compared between patients with and without PBI.

\section{Inclusion and exclusion criteria}

Patients who underwent initial liver resection for HCC, but were positive for HBsAg were excluded from the study. Patients who were negative for $\mathrm{HBsAg}$ and $\mathrm{HBcAb}$ but positive for HBsAb, and those who were positive for $\mathrm{HCV}$ antibody but negative for HCV-RNA were also excluded. In addition, patients whose HBsAb or $\mathrm{HBcAb}$ status had not been determined were also excluded.

\section{Indications for liver resection}

Indicators for liver resection were determined by assessing the liver functional reserve according to Clinical Practice Guidelines for Hepatocellular Carcinoma in Japan [24]. Briefly, liver resection was contraindicated in patients who had refractory ascites, hepatic encephalopathy, or both
[25]. Patients with up to three lesions were candidates for liver resection.

In order to assess the existence of esophageal varices, gastrointestinal endoscopy was performed preoperatively for all candidates considered eligible for liver resection. Patients with F3 varices (largest size) or F2 varices (enlarged tortuous) or blue varices positive for red color signs were treated prophylactically using esophageal variceal ligation [26].

\section{Surgical procedures}

Liver resection was performed on all patients according to criteria based on liver function, as described previously [27]. Briefly, transection of the liver was performed under ultrasonographic guidance using the clamp-crushing method with the inflow-blood-occlusion technique. Curative resection was defined as the complete removal of recognizable HCC diagnosed preoperatively. Postoperative complications were stratified according to the Clavien-Dindo classification [28], which defines morbidities as complications with a score of $\geq$ IIIa. Complications specific to liver resection were defined as previously described [29].

\section{Follow-up after surgery}

All patients were followed for postoperative recurrence, as described previously [30]. Briefly, tumor marker levels were measured, and imaging studies, including computed tomography and ultrasonography, were performed every 3 months on all patients. Recurrence was diagnosed by dynamic computed tomography and/or gadolinium-ethoxybenzyl-diethylenetriamine pentaacetic acid-enhanced magnetic resonance imaging. The date of recurrence was defined as the date of examination when the recurrence of $\mathrm{HCC}$ was detected. In patients with recurrent HCC, the recurrence-free period was defined as the time from the date of surgery to the date of recurrence. Recurrent HCC was managed aggressively by repeated liver resection, transcatheter arterial chemoembolization, radiofrequency ablation, and chemotherapy according to the HCC status and liver function at the time of recurrence. Liver function was estimated 6 months after operation based on ChildPugh classification.

\section{Statistical analysis}

Data collected from each group were statistically analyzed with Fisher's exact test and the Wilcoxon ranksum test. Survival curves were generated using the Kaplan-Meier method and compared by the log-rank test. Prognostic factors for overall survival were identified with the Cox proportional hazards regression model. A $p$ value of less than 0.10 was set as the cut-off value for elimination. The following 25 variables considered as potential confounders were examined; age ( $\geq 75$ years vs $<75$ years), 
sex, PBI, alcohol abuse, diabetes mellitus, esophageal varices, AST $(\geq 80 \mathrm{U} / \mathrm{L}$ vs $<80 \mathrm{U} / \mathrm{L})$, ALT $(\geq 80 \mathrm{U} / \mathrm{L}$ vs $<80 \mathrm{U} /$ $\mathrm{L})$, platelet count $\left(\geq 10 \times 10^{4} \mu \mathrm{L}\right.$ vs $\left.<10 \times 10^{4} \mu \mathrm{L}\right)$, creatinine ( $\geq 1.2 \mathrm{mg} / \mathrm{dL}$ vs $<1.2 \mathrm{mg} / \mathrm{dL}$, Child-Pugh classification (A vs B), indocyanine green clearance rate at $15 \mathrm{~min}(\geq 15 \%$ vs $<15 \%$ ), serum alpha-fetoprotein level ( $\geq 100 \mathrm{ng} / \mathrm{mL}$ vs $<$ $100 \mathrm{ng} / \mathrm{mL}$ ), serum des-gamma-carboxy prothrombin level $(\geq 100 \mathrm{ng} / \mathrm{mL}$ vs $<100 \mathrm{ng} / \mathrm{mL}$ ), operation time $(\geq 300 \mathrm{~min}$ vs $<300 \mathrm{~min}$ ), clamp time ( $\geq 75 \mathrm{~min}$ vs $<75 \mathrm{~min}$ ), bleeding $(\geq 300 \mathrm{~mL}$ vs $<300 \mathrm{~mL}$ ), transfusion, resection (anatomic vs non-anatomic), multiple tumors, tumor size ( $\geq 3.0 \mathrm{~cm}$ vs $<$ $3.0 \mathrm{~cm}$ ), differentiation grade (well-differentiated vs moderately differentiated vs poorly differentiated), tumor thrombus of the portal vein and hepatic vein, tumor exposure at surgery, and liver cirrhosis. In all analyses, a $p$ value $<0.05$ was considered to be statistically significant.

\section{Results}

\section{Patients}

Of the 1053 total patients that underwent curative liver resection for HCC during the time period of the study, 872 (82.8\%) were negative for HBsAg (Fig. 1). After excluding patients based on the criteria described above, 428 (40.6\%) patients, including 165 (18.6\%) patients with PBI, were positive for HCV antibody and HCV-RNA; and 317 (30.1\%) patients, including 104 (9.8\%) patients with PBI were negative for HCV antibody. The demographics and background information for the HCV-positive patients are listed in Table 1. The frequency of alcohol abuse also trended higher in the PBI patients compared to the non-PBI patients $(23.6 \%$ vs. $16.7 \%$, respectively), but statistical significance was not detected $(p=0.080)$. As seen in Table 2 , there was no significant or trending variable between the PBI and non-PBI patients in the group of $\mathrm{HCC}$ patients negative for $\mathrm{HCV}$ antibody (non-B non-C).

\section{Operative data}

Among the patients positive for $\mathrm{HCV}$ antibody and HCV-RNA, the amount of bleeding during surgery for PBI patients (median $316 \mathrm{~mL}$; range, 5-3887) was significantly greater compared to that of non-PBI patients $(240 \mathrm{~mL} ; 10-4530 ; p=0.029)$ (Table 1$)$. In comparison, there was no significant variable between the PBI and non-PBI patients negative for HCV (Table 2). Complication rates and histological diagnosis were also not significantly different between the two PBI groups in both $\mathrm{HCV}$-positive and HCV-negative patients.

\section{Survival of HCV-positive patients}

After a median follow-up of 3.6 years (range, 0.2-14.2), a total of 290 patients (67.7\%) experienced HCC recurrence; 277 patients $(95.5 \%)$ in the remnant liver, eight patients $(2.7 \%)$ in distant sites such as the lung, bone, and lymph nodes, and five patients (1.7\%) with both intra- and extra-hepatic recurrences. The treatments for recurrent HCC were not significantly different between the two groups (Table 3). During the follow-up period, 105 (63.6\%) patients with PBI and 190 (72.2\%) patients

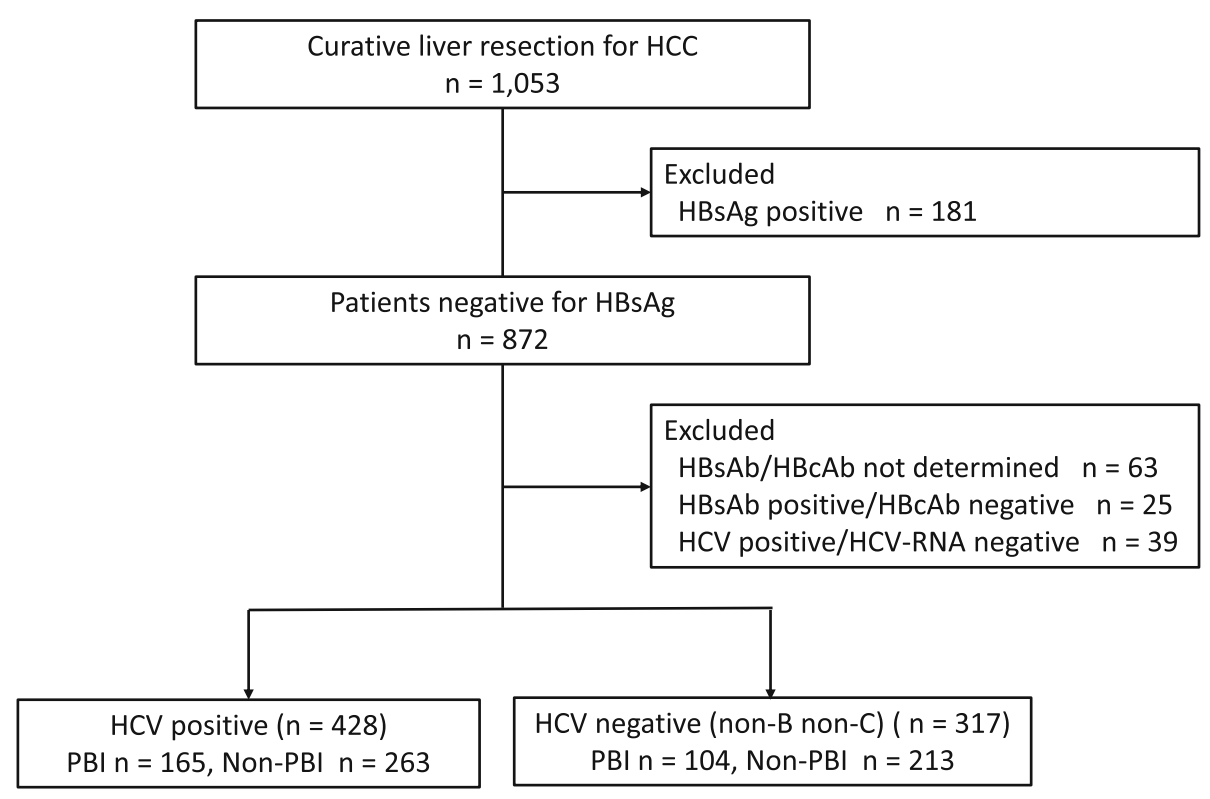

Fig. 1 Flow diagram detailing patient recruitment and follow-up study group assignment. The number within each group is indicated (n). HCC, hepatocellular carcinoma; HBsAg, hepatitis B surface antigen; HBsAb, anti-hepatitis B surface antibody; HBcAb, anti-hepatitis B core antibody; HCV, hepatitis $C$ virus; $\mathrm{PBI}$, prior hepatitis $B$ virus infection 
Table 1 Patient background (HCV-positive)

\begin{tabular}{|c|c|c|c|}
\hline & $\begin{array}{l}\mathrm{PBI} \\
(n=165)\end{array}$ & $\begin{array}{l}\text { Non-PBI } \\
(n=263)\end{array}$ & $P$ \\
\hline Age, years & $71(53-85)$ & $70(32-86)$ & 0.13 \\
\hline Sex, male (\%) & $121(73.3)$ & $183(69.5)$ & 0.44 \\
\hline Alcoholic (\%) & $39(23.6)$ & $44(16.7)$ & c \\
\hline Diabetes mellitus (\%) & $40(24.2)$ & $74(28.1)$ & \\
\hline Varices (\%) & $48(29.0)$ & $75(28.5)$ & 0 \\
\hline Platelet count & $13.3(3.2-35.1)$ & $11.7(3.2-66.0)$ & 0.13 \\
\hline Creatinine & $0.75(0.35-8.34)$ & $9.24(0.34-9.24)$ & 0.35 \\
\hline Child-Pugh, A (\%) & $124(75.1)$ & $204(77.5)$ & 0 \\
\hline ICGR15, \% & $15.2(3.6-48.4)$ & $14.8(2.0-65.5)$ & \\
\hline Alpha-fetoprotein, $\mathrm{ng} / \mathrm{mL}$ & $25(1-23,881)$ & $18(1-93,075)$ & c \\
\hline DCP & $45(2-64,386)$ & $44(1-75,000)$ & 0.59 \\
\hline \multicolumn{4}{|l|}{ Operation data } \\
\hline Operation time, min & 331 (139-1004) & $300(120-810)$ & 0.00 \\
\hline Bleeding, mL & $316(5-3887)$ & $240(10-4530)$ & 0.02 \\
\hline Pringle time, min & $72(0-860)$ & $66(0-516)$ & 0.16 \\
\hline Transfusion (\%) & $9(5.4)$ & $16(6.0)$ & 0.83 \\
\hline Anatomic resection (\%) & $57(34.5)$ & $91(34.6)$ & 1.00 \\
\hline \multicolumn{4}{|l|}{ Complications } \\
\hline Overall (\%) & $75(45.4)$ & $111(42.2)$ & 0.54 \\
\hline Morbidity (\%) & $59(35.7)$ & $93(35.3)$ & 1.00 \\
\hline Re-operation (\%) & $5(3.0)$ & $8(3.0)$ & 1 \\
\hline Mortality (\%) & $0(0)$ & $0(0)$ & 1.00 \\
\hline \multicolumn{4}{|l|}{ Pathology } \\
\hline Multiple (\%) & $51(30.9)$ & $67(25.4)$ & 0.22 \\
\hline Size, $\mathrm{cm}$ & $2.8(0.7-12.5)$ & $2.5(0.7-18.0)$ & 0.17 \\
\hline \multicolumn{4}{|l|}{ Differentiation grade } \\
\hline well/moderately/poorly & $36 / 114 / 15$ & $59 / 175 / 29$ & 0.80 \\
\hline Vascular invasion (\%) & $39(23.6)$ & $74(25.8)$ & 0.64 \\
\hline Tumor exposure (\%) & $11(6.6)$ & $23(8.7)$ & 0.46 \\
\hline Cirrhosis (\%) & $75(45.4)$ & $133(50.5)$ & 0.32 \\
\hline
\end{tabular}

Data are presented as median with range, if not specified HCV Hepatitis C virus, PBI Prior hepatitis B virus infection, ICGR15 Indocyanine green clearance rate at $15 \mathrm{~min}, D C P$ Des-gamma carboxyprothrombin

without PBI were diagnosed as Child-Pugh classification A $(p=0.068)$.

In the patients with $\mathrm{HCV}$-positive, the median overall survival of PBI patients was 4.7 years $(95 \%$ confidence interval $[\mathrm{CI}], 3.9-5.9)$, which was significantly shorter compared with that of non-PBI patients (6.6 years, $5.3-9.8 ; p=0.015$ ) (Fig. 2). On the other hand, there was no significant difference in the median recurrence-free survival between the two groups (1.8 years, [95\% CI, $1.4-2.0$ ] vs 2.0 years, $1.7-$ $2.3 ; p=0.205)$. The overall survival and recurrencefree survival rates at 5 years were 45.9 and $17.0 \%$ in PBI patients, respectively, and 62.0 and $22.1 \%$ in non-PBI
Table 2 Patient background (non-B non-C)

\begin{tabular}{llll}
\hline & $\begin{array}{l}\text { PBI } \\
(n=104)\end{array}$ & $\begin{array}{l}\text { Non-PBI } \\
(n=213)\end{array}$ & $P$ \\
\hline Age, years & $70(44-85)$ & $69(36-84)$ & 0.250 \\
Sex, male (\%) & $86(82.6)$ & $177(83.0)$ & 1.000 \\
Alcoholic (\%) & $45(43.2)$ & $82(38.4)$ & 0.464 \\
Diabetes mellitus (\%) & $50(48.0)$ & $96(45.0)$ & 0.632 \\
Varices (\%) & $18(17.3)$ & $33(15.4)$ & 0.745 \\
Platelet count & $18.0(4.3-66.5)$ & $17.7(3.7-44.3)$ & 0.851 \\
Creatinine & $0.78(0.35-2.44)$ & $0.78(0.36-2.37)$ & 0.448 \\
Child-Pugh, A (\%) & $102(90.3)$ & $190(89.2)$ & 0.846 \\
ICGR15, \% & $10.6(2.3-48.0)$ & $11.8(1.3-74.6)$ & 0.254 \\
Alpha-fetoprotein, ng/mL & $7(1-145,900)$ & $7(1-39,596)$ & 0.578 \\
DCP & $126(6-75,000)$ & $142(8-75,000)$ & 0.553
\end{tabular}

Operation data

\begin{tabular}{|c|c|c|c|}
\hline Operation time, $\min$ & $325(130-609)$ & $334(97-855)$ & 0.888 \\
\hline Bleeding, $\mathrm{mL}$ & $261(10-2398)$ & $384(5-2065)$ & 0.133 \\
\hline Pringle time, min & $71(12-222)$ & $67(0-485)$ & 0.309 \\
\hline Transfusion (\%) & $7(6.7)$ & $24(11.2)$ & 0.232 \\
\hline Anatomic resection (\%) & $44(42.3)$ & $87(40.8)$ & 0.809 \\
\hline \multicolumn{4}{|l|}{ Complications } \\
\hline Overall (\%) & $30(29.2)$ & $70(32.8)$ & 0.520 \\
\hline Morbidity (\%) & $26(25.0)$ & $53(24.8)$ & 0.981 \\
\hline Re-operation (\%) & $4(3.8)$ & $4(1.8)$ & 0.446 \\
\hline Mortality (\%) & $0(0)$ & $0(0)$ & 1.000 \\
\hline \multicolumn{4}{|l|}{ Pathology } \\
\hline Multiple (\%) & $26(25.0)$ & $54(25.3)$ & 1.000 \\
\hline Size, $\mathrm{cm}$ & $4.0(1.0-15.5)$ & $0.9(4.3-20.5)$ & 0.438 \\
\hline \multicolumn{4}{|l|}{ Differentiation grade } \\
\hline well/moderately/poorly & $14 / 77 / 13$ & $35 / 156 / 22$ & 0.709 \\
\hline Vascular invasion (\%) & 35 (33.6) & $81(38.0)$ & 0.459 \\
\hline Tumor exposure (\%) & $12(11.5)$ & $13(6.5)$ & 0.119 \\
\hline Cirrhosis (\%) & $22(21.1)$ & $45(21.1)$ & 1.000 \\
\hline
\end{tabular}

Data are presented as median with range, if not specified

$P B I$ Prior hepatitis B virus infection, ICGR15 Indocyanine green clearance rate at $15 \mathrm{~min}, D C P$ Des-gamma carboxyprothrombin

Table 3 Treatment after recurrence (HCV positive)

\begin{tabular}{llll}
\hline Treatments & $\begin{array}{l}\text { PBI } \\
(n=117)\end{array}$ & $\begin{array}{l}\text { Control } \\
(n=173)\end{array}$ & $P$ \\
\hline Resection $^{\mathrm{a}}$ & $48(41.0)$ & $65(37.5)$ & 0.623 \\
Transcatheter arterial chemoembolization & $58(49.5)$ & $96(55.4)$ & 0.339 \\
Radiofrequency ablation & $3(2.5)$ & $4(2.3)$ & 1.000 \\
Chemotherapy & $4(3.4)$ & $4(2.3)$ & 0.718 \\
Radiation & $1(0.8)$ & $2(1.1)$ & 1.000 \\
None & $3(2.5)$ & $2(1.1)$ & 0.396 \\
\hline
\end{tabular}

HCV Hepatitis C virus, $P B I$ Prior hepatitis B virus infection aincluding resection for extra-hepatic tumors 

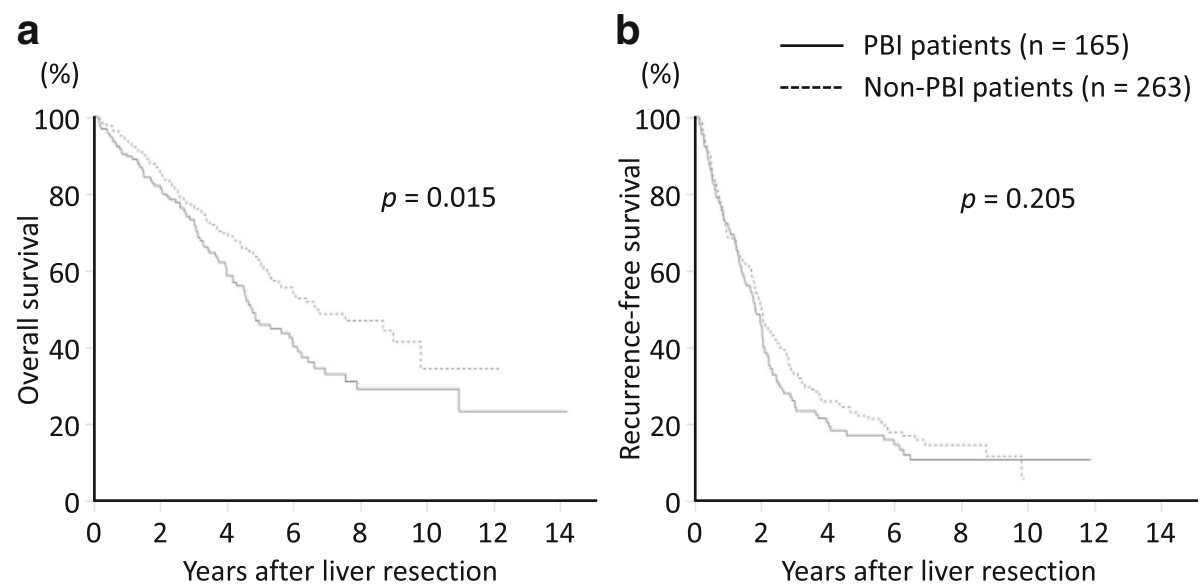

Fig. 2 Survival outcomes following liver resection in HCV patients. a The overall survival of patients with prior HBV infection (PBI) was significantly shorter compared to those without PBI $(p=0.015)$. b The recurrence-free survival was not significantly different between the two groups $(p=$ 0.205). Study group sizes are indicated ( $n$ )

patients, respectively. On multivariate analysis, independent factors for overall survival were PBI (hazard ratio $1.38[95 \%$ CI, 1.02-1.87]; $p=0.033)$, multiple tumors $(p=0.007)$, tumor size $(p=0.002)$, and liver cirrhosis $(p<0.001)$ (Table 4).

\section{Survival of non-B non-C patients}

After a median follow-up of 3.0 years (range, $0.2-12.8$ years) for the non- $B$ non- $C$ patients in the study, a total of 192 patients (60.5\%) experienced HCC recurrence; 160 patients $(83.3 \%)$ in the remnant liver, 22 patients (11.4\%) in distant sites, and 10 patients $(5.2 \%)$ with both intra- and extra-hepatic recurrences.

For the 104 patients with PBI and the 213 patients without PBI in this group, the median overall survival was 6.5 years $(95 \% \mathrm{CI}, 4.8-7.1)$ and 7.5 years (5.5-NA; $p=0.932$ ), respectively. The recurrence-free survivals were 2.4 years $(95 \% \mathrm{CI}, 1.5-3.3)$ and 2.2 years $(1.7-2.7$; $p=0.983$ ), respectively (Fig. 3 ). The 5 -year overall survival rates were 61.2 and $59.9 \%$, and 5-year recurrence-free survival rates were 25.3 and $27.7 \%$ in the two groups, respectively.

\section{Discussion}

We found that PBI was an unfavorable prognostic factor, negatively impacting survival rates following liver resection for $\mathrm{HCV}$-related $\mathrm{HCC}$, while it did not affect the surgical outcomes in non-B non-C HCC patients. Therefore, our findings suggest that $\mathrm{PBI}$ and $\mathrm{HCV}$ in conjunction with each other affect the survival of patients that have undergone resection for HCC.

Consistent with the previous report that $\mathrm{HCV}$ and OBI co-infected patients are at an increased risk of lower survival [9], we showed that overall survival following resection for $\mathrm{HCC}$ was significantly shorter in $\mathrm{HCV}$
Table 4 Prognostic factors for survival in patients with HCV

\begin{tabular}{|c|c|c|c|c|}
\hline \multirow[t]{2}{*}{ Variables } & \multicolumn{2}{|l|}{ Univariate } & \multicolumn{2}{|l|}{ Multivariate } \\
\hline & Odds ratio & $p$ & Odds ratio & $p$ \\
\hline Age & $1.16(0.78-1.68)$ & 0.446 & & \\
\hline Gender, male & $0.79(0.54-1.14)$ & 0.215 & & \\
\hline Prior HBV infection & $1.45(1.06-1.99)$ & 0.019 & $1.38(1.02-1.87)$ & 0.033 \\
\hline Alcoholic & $0.82(0.54-1.22)$ & 0.348 & & \\
\hline Diabetes mellitus & $1.05(0.72-1.51)$ & 0.755 & & \\
\hline Varices & $1.05(0.74-1.49)$ & 0.747 & & \\
\hline AST & $0.93(0.61-1.37)$ & 0.747 & & \\
\hline ALT & $0.69(0.45-1.03)$ & 0.171 & & \\
\hline Platelet count & $0.84(0.62-1.16)$ & 0.303 & & \\
\hline Creatinine & $1.46(0.72-2.62)$ & 0.242 & & \\
\hline Child-Pugh, B & $1.17(0.79-1.72)$ & 0.413 & & \\
\hline ICGR15 & $1.05(0.74-1.48)$ & 0.762 & & \\
\hline Alpha-fetoprotein & $0.91(0.62-1.29)$ & 0.617 & & \\
\hline DCP & $1.22(0.87-1.72)$ & 0.241 & & \\
\hline Operation time & $1.04(0.70-1.54)$ & 0.822 & & \\
\hline Pringle time & $0.88(0.60-1.29)$ & 0.513 & & \\
\hline Bleeding & $0.91(0.64-1.28)$ & 0.606 & & \\
\hline Transfusion & $1.02(0.50-1.87)$ & 0.947 & & \\
\hline Anatomic resection & $0.90(0.63-1.27)$ & 0.570 & & \\
\hline Multiple & $1.76(1.23-2.50)$ & 0.002 & $1.53(1.12-2.08)$ & 0.007 \\
\hline Size & $1.55(1.10-2.20)$ & 0.012 & $1.62(1.18-2.22)$ & 0.002 \\
\hline Differentiation grade & $1.45(0.99-2.17)$ & 0.517 & & \\
\hline Vascular invasion & $1.38(0.96-1.96)$ & 0.077 & $1.34(0.94-1.86)$ & 0.094 \\
\hline Tumor exposure & $1.33(0.74-2.24)$ & 0.313 & & \\
\hline Cirrhosis & $1.50(1.07-2.12)$ & 0.018 & $1.68(1.24-2.29)$ & $<0.001$ \\
\hline
\end{tabular}

HCV Hepatitis C virus infection, HBV Hepatitis B virus infection, AST Aspartate aminotransferase, ALT Alanine aminotransferase, ICGR15 Indocyanine green clearance rate at $15 \mathrm{~min}, D C P$ Des-gamma carboxyprothrombin 

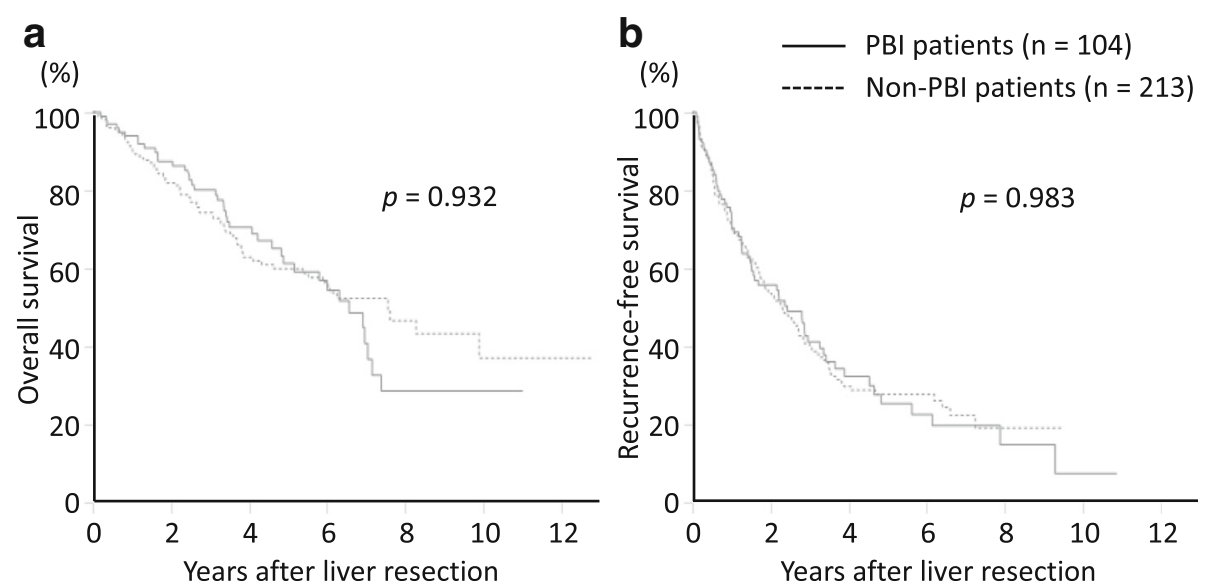

Fig. 3 Survival outcomes following liver resection in non-B non-C patients. a The overall survival of patients with prior HBV infection (PBI) was not significantly different compared to those without PBI $(p=0.932) \mathbf{b}$ The recurrence-free survival was not significantly different between the two groups $(p=0.983)$. Study group sizes are indicated $(n)$

patients with PBI compared with those without PBI. On the other hand, no association between $\mathrm{PBI}$ and survival was observed in non-B non-C HCC patients, which strongly suggests that PBI by itself is not a significant factor. However, when other significant immunosuppressive causes of liver damage co-exist such as $\mathrm{HCV}$ [31], human immunodeficiency virus infection [32], and immunosuppression therapy $[18,20]$, PBI or OBI may contribute to a worsening of the course of chronic liver disease. In this study, liver function trended to be worse in PBI patients with HCV-positive, which could account for the poorer overall survival of such patients despite of no significant difference of recurrence-free survival between the HCV-positive patients with and without PBI. Furthermore, surgical stress, as well as HCV infection, might also accelerate the deteriorative outcomes of PBI patients undergoing resection of HCC.

Compared with non-B non-C patients with $\mathrm{PBI}$, overall survival rate at 5 years for $\mathrm{HCV}$ patients with $\mathrm{PBI}$ in this study was lower due to the high frequency of cirrhosis (advanced fibrosis), Child-Pugh classification B (poor liver function), and varices (portal hypertension). On the other hand, despite of the poorer liver function, survival rates of $\mathrm{HCV}$ patients without $\mathrm{PBI}$ were similar to those of non-B non-C patients without $\mathrm{PBI}$, which also supports the idea that there may be some negative synergistic effects on the survival of patients after resection of HCC between PBI and HCV infections [31].

It is debatable whether PBI or OBI plays a pivotal role in the progression of fibrosis in $\mathrm{HCV}$ patients $[5,7,10,11]$. In our study, the prevalence of patients with cirrhosis in the PBI group was not statistically different from those in the non-PBI group. Similarly, there was no association between PBI and the progression of cirrhosis in non- $\mathrm{B}$ non-C HCC patients, suggesting that $\mathrm{PBI}$ was not a predictor for cirrhosis, regardless of HCV-infection status. However, it should be noted that the population in this study was limited to candidates for surgery, and the results may not be simply comparable to that of previous studies.

Despite the numerous reports about the impact of PBI or OBI on HCV infection, there is only one report to date that analyzed survival after resection for patients with HCV-related HCC in association with PBI [15]. In contrast to our findings, they reported that the overall survival was not significantly different between the patients with and without PBI. This discrepancy may be attributed to the significantly higher frequency of anatomic resection in the HBcAb-positive group $(69.7 \%$ vs $50.0 \%)$, despite similar liver function of the two groups. This might initiate the negative effects of PBI, and the positive effects of anatomic resection on survival.

On the other hand, the comparative study reported by $\mathrm{Wu}$ et al. focused on $\mathrm{OBI}$ in patients with non-B non-C HCC [16]. The period of recurrence-free survival was significantly longer, and the overall survival trended to be longer. Conversely, in another report by Itoh and colleagues, there was no significant differences in overall or recurrence-free survivals between non-B non-C HCC patients with and without PBI [15]. This is due to a higher recurrence-free survival rate at 5 years for patients without OBI (about 50\%) in the former report [16], although overall and recurrence-free survival of patients with OBI are consistent with our data. In any case, there were a relatively small number of participants in their studies, and large-scale studies should be performed to justify these procedures in the future. 


\section{Conclusions}

Our data that PBI negatively influenced the clinical outcomes in $\mathrm{HCC}$ patients with $\mathrm{HCV}$ infection that underwent $\mathrm{HCC}$ resection, but not in those without $\mathrm{HCV}$. This might be attributed to the concept that PBI works as a co-effector with $\mathrm{HCV}$ to impact the outcomes for HCC patients.

\section{Abbreviations}

HBCAb: Anti-hepatitis B core antibody; HBsAb: Anti-hepatitis B surface antibody; HBsAg: Hepatitis B surface antigen; HBV: Hepatitis B virus; HCC: Hepatocellular carcinoma; HCV: Hepatitis C virus; OBI: Occult hepatitis B virus infection; PBI: Prior hepatitis B virus infection

\section{Acknowledgements}

Not applicable

\section{Authors' contributions}

YM designed the study, data acquisition, and wrote the initial draft of the manuscript; $T$ conceived of the study, and participated in its design and coordination and helped to draft the manuscript; $\mathrm{HN}, \mathrm{TH}$, and MMorig acquired the data; KM, TK, SM, MMoriy revised the article for clinical content. All authors have read and approved the final version of the manuscript.

\section{Funding}

This research was supported by AMED under Grant Number JP18hk0102049h0001 and a grants-in-aid of The 106th Annual Congress of JSS Memorial Surgical Research Fund, Tokyo, Japan. The funding body supported the data collection used in this study. The funding body has no role in the design of the study and analysis and interpretation of data and in writing the manuscript.

\section{Availability of data and materials}

Data and materials analyzed in this study are not available due to the pretection of individual privacy, but are available from the corresponding author on reasonable request.

\section{Ethics approval and consent to participate}

Each participant provided written, informed consent, and this study was approved by the institutional review board of Nihon University (RK-141209-4)

\section{Consent for publication}

Not applicable

\section{Competing interests}

The authors declare that they have no competing interests.

\section{Author details}

'Department of Digestive Surgery, Nihon University School of Medicine, 30-1, Oyaguchikami-cho, Itabashi-ku, Tokyo 173-8610, Japan. ${ }^{2}$ Department of Infectious Diseases, University of Tokyo Faculty of Medicine, Tokyo, Japan. ${ }^{3}$ Department of Gastroenterology and Hepatology, Nihon University School of Medicine, Tokyo, Japan.

Received: 1 March 2019 Accepted: 15 August 2019

Published online: 19 August 2019

\section{References}

1. Raimondo G, Allain JP, Brunetto MR, Buendia MA, Chen DS, Colombo M, et al. Statements from the Taormina expert meeting on occult hepatitis B virus infection. J Hepatol. 2008:49:652-7.

2. Matsuzaki $Y$, Sato M, Saito Y, Karube M, Doy M, Shoda J, et al. The role of previous infection of hepatitis B virus in $\mathrm{Hbs}$ antigen negative and anti-HCV negative Japanese patients with hepatocellular carcinoma: etiological and molecular biological study. J Exp Clin Cancer Res. 1999:18:379-89.

3. Tamori A, Nishiguchi S, Kubo S, Narimatsu T, Habu D, Takeda T, et al. HBV DNA integration and HBV-transcript expression in non-B, non-C hepatocellular carcinoma in Japan. J Med Virol. 2003;71:492-8.
4. Adachi S, Shibuya A, Miura Y, Takeuchi A, Nakazawa T, Saigenji K. Impact of occult hepatitis B virus infection and prior hepatitis B virus infection on development of hepatocellular carcinoma in patients with liver cirrhosis due to hepatitis C virus. Scand J Gastroenterol. 2008:43:849-56.

5. Giannini E, Ceppa P, Botta F, Fasoli A, Romagnoli P, Ansaldi F, et al. Previous hepatitis $B$ virus infection is associated with worse disease stage and occult hepatitis $B$ virus infection has low prevalence and pathogenicity in hepatitis C virus-positive patients. Liver Int. 2003;23:12-8.

6. Kubo S, Tamori A, Ohba K, Shuto T, Yamamoto T, Tanaka H, et al. Previous or occult hepatitis B virus infection in hepatitis C virus-associated hepatocellular carcinoma without hepatic fibrosis. Dig Dis Sci. 2001:46:2408-14.

7. Sagnelli E, Coppola N, Scolastico C, Filippini P, Santantonio T, Stroffolini T, et al. Virologic and clinical expressions of reciprocal inhibitory effect of hepatitis B, C, and delta viruses in patients with chronic hepatitis. Hepatology. 2000;32:1106-10.

8. Ikeda K, Marusawa H, Osaki Y, Nakamura T, Kitajima N, Yamashita Y, et al. Antibody to hepatitis B core antigen and risk for hepatitis C-related hepatocellular carcinoma: a prospective study. Ann Intern Med. 2007;146:649-56.

9. Squadrito G, Cacciola I, Alibrandi A, Pollicino T, Raimondo G. Impact of occult hepatitis B virus infection on the outcome of chronic hepatitis C. J Hepatol. 2013;59:696-700.

10. Helmy A, Al-Sebayel MI. Isolated antibody to hepatitis B core antigen in patients with chronic hepatitis C virus infection. World J Gastroenterol. 2006; 12:4406-10.

11. Levast M, Larrat S, Thelu MA, Nicod S, Plages A, Cheveau A, et al. Prevalence and impact of occult hepatitis B infection in chronic hepatitis $C$ patients treated with pegylated interferon and ribavirin. J Med Virol. 2010;82:747-54.

12. Bruno S, Crosignani A, Maisonneuve P, Rossi S, Silini E, Mondelli MU. Hepatitis C virus genotype $1 \mathrm{~b}$ as a major risk factor associated with hepatocellular carcinoma in patients with cirrhosis: a seventeen-year prospective cohort study. Hepatology. 2007;46:1350-6.

13. Hasegawa I, Orito E, Tanaka Y, Hirashima N, Sakakibara K, Sakurai M, et al. Impact of occult hepatitis B virus infection on efficacy and prognosis of interferon-alpha therapy for patients with chronic hepatitis C. Liver Int. 2005;25:247-53

14. Lok AS, Everhart JE, Di Bisceglie AM, Kim HY, Hussain M, Morgan TR, et al. Occult and previous hepatitis B virus infection are not associated with hepatocellular carcinoma in United States patients with chronic hepatitis C. Hepatology. 2011;54:434-42.

15. Itoh S, Yoshizumi T, Tomino T, Nagatsu A, Motomura T, Harada N, et al. Associations between antibody to hepatitis B core antigen positivity and outcomes in hepatocellular carcinoma patients undergoing hepatic resection. Hepatol Res. 2017:48:E155-61.

16. Wu ZF, Xu Z, Li WS, Zhang HB, Yang N, Yao XQ, et al. Impact of occult hepatitis $B$ virus infection on outcome after resection for non-B non-C hepatocellular carcinoma. J Surg Res. 2015;193:153-60.

17. Coppola N, Onorato L, Pisaturo M, Macera M, Sagnelli C, Martini S, et al. Role of occult hepatitis B virus infection in chronic hepatitis C. World J Gastroenterol. 2015;21:11931-40.

18. Hui CK, Sun J, Au WY, Lie AK, Yueng YH, Zhang HY, et al. Occult hepatitis B virus infection in hematopoietic stem cell donors in a hepatitis B virus endemic area. J Hepatol. 2005;42:813-9.

19. Nakamoto S, Kanda T, Nakaseko C, Sakaida E, Ohwada C, Takeuchi M, et al. Reactivation of hepatitis B virus in hematopoietic stem cell transplant recipients in Japan: efficacy of nucleos(t) ide analogues for prevention and treatment. Int J Mol Sci. 2014;15:21455-67.

20. Yeo W, Chan TC, Leung NW, Lam WY, Mo FK, Chu MT, et al. Hepatitis $B$ virus reactivation in lymphoma patients with prior resolved hepatitis B undergoing anticancer therapy with or without rituximab. J Clin Oncol. 2009;27:605-11.

21. Raimondo G, Pollicino T, Cacciola I, Squadrito G. Occult hepatitis B virus infection. J Hepatol. 2007:46:160-70.

22. El-Sherif A, Abou-Shady M, Abou-Zeid H, Elwassief A, Elbahrawy A, Ueda Y, et al. Antibody to hepatitis B core antigen as a screening test for occult hepatitis B virus infection in Egyptian chronic hepatitis C patients. J Gastroenterol. 2009:44:359-64.

23. Urbani S, Fagnoni F, Missale G, Franchini M. The role of anti-core antibody response in the detection of occult hepatitis B virus infection. Clin Chem Lab Med. 2010;48:23-9.

24. Kokudo N, Hasegawa K, Akahane M, Igaki H, Izumi N, Ichida T, et al. Evidence-based clinical practice guidelines for hepatocellular carcinoma: the 
Japan Society of Hepatology 2013 update (3rd JSH-HCC guidelines). Hepatol Res. 2015;45:123-7.

25. Makuuchi M, Kosuge T, Takayama T, Yamazaki S, Kakazu T, Miyagawa S, et al. Surgery for small liver cancers. Semin Surg Oncol. 1993;9:298-304.

26. Yamazaki S, Takayama T, Nakamura M, Higaki T, Matsuoka S, Mizuno S, et al. Prophylactic impact of endoscopic treatment for esophageal varices in liver resection: a prospective study. J Gastroenterol. 2014;49:917-22.

27. Takayama T, Makuuchi M, Kubota K, Harihara Y, Hui AM, Sano K, et al. Randomized comparison of ultrasonic vs clamp transection of the liver. Arch Surg. 2001;136:922-8.

28. Dindo D, Demartines N, Clavien PA. Classification of surgical complications: a new proposal with evaluation in a cohort of 6336 patients and results of a survey. Ann Surg. 2004;240:205-13.

29. Midorikawa Y, Kubota K, Takayama T, Toyoda H, ljichi M, Torzilli G, et al. A comparative study of postoperative complications after hepatectomy in patients with and without chronic liver disease. Surgery. 1999;126:484-91.

30. Midorikawa Y, Takayama T, Shimada K, Nakayama H, Higaki T, Moriguchi M, et al. Marginal survival benefit in the treatment of early hepatocellular carcinoma. J Hepatol. 2013;58:306-11.

31. Raimondo G, Pollicino T, Squadrito G. What is the clinical impact of occult hepatitis B virus infection? Lancet. 2005;365:638-40.

32. Vento S, di Perri G, Luzzati R, Garofano T, Concia E, Bassetti D. Clinical reactivation of hepatitis $B$ in anti-HBs-positive patients with AIDS. Lancet. 1989:1:332-3.

\section{Publisher's Note}

Springer Nature remains neutral with regard to jurisdictional claims in published maps and institutional affiliations.

Ready to submit your research? Choose BMC and benefit from:

- fast, convenient online submission

- thorough peer review by experienced researchers in your field

- rapid publication on acceptance

- support for research data, including large and complex data types

- gold Open Access which fosters wider collaboration and increased citations

- maximum visibility for your research: over $100 \mathrm{M}$ website views per year

At BMC, research is always in progress.

Learn more biomedcentral.com/submissions 